\title{
Performance Enhancement of a Photovoltaic Module by Passive Cooling Using Water-Based Aluminum Oxide Nano-Fluid
}

\author{
Mohammad A. Hamdan' \\ 1 School of Engineering, Department of Mechanical Engineering, The University of Jordan, Queen Rania St, \\ Amman 11942, Jordan \\ e-mail: mhamdan@ju.edu.jo
}

\begin{abstract}
The performance of a PV (photovoltaic) module relies heavily on the operating temperature. The aim of the current study was to improve PV performance by passive cooling with nano-coated aluminum fins attached to the backside of the photovoltaic panels. Four identical PV panels were installed side by side for simultaneous measurements. The first one (B) is a basic PV that was used for comparison purposes, the second one (N) PV, which is coated with water-based $\mathrm{Al}_{2} \mathrm{O}_{3}$ nano-fluid, the third is finned $\mathrm{PV}(\mathrm{F})$, with fins being attached to its backside and the $\mathrm{Al}_{2} \mathrm{O}_{3}$ nano-fluid coated fins are attached to the backside of the fourth PV (FN). The hourly electrical generated power by each PV, I-V, and I_V curves for each PV were recorded and stored using I-V Checker. In addition, the backside temperature of each PV and the ambient temperature were measured on an hourly basis using K-type thermocouples; the measured temperature values were stored in a data logger. It was found that the (FN) PV gave the best performance compared to the base unit, with an increase in the generated power by $5.77 \%$, followed by the nanocoated (N) PV with an increase of $2.14 \%$ and finally the finned (F) PV with an increase of $0.74 \%$. Furthermore, the PV with the nano-coated fins exhibits the lower temperature $31^{\circ} \mathrm{C}$, followed by the nano-coated PV, and finally the fined PV, with the backside average temperature of the basic unit being $39^{\circ} \mathrm{C}$
\end{abstract}

Keywords: PV cooling, nanotechnology, PV performance, fined PV.

\section{INTRODUCTION}

Solar energy is turned into electricity using photovoltaic cells (PV), which have a maximum efficiency of roughly $15-20 \%$, depending on the type of solar cell. Almost all of the solar radiation that reaches the $(\mathrm{PV})$ is reflected or converted to thermal energy. This causes the cell temperature to increase and consequently the photovoltaic efficiency to drop. The overall efficiency of photovoltaic cells has been shown to drop substantially with temperature growth (Grubišić-Čabo et al., 2016). The rate of decrease ranges from $0.25 \%$ to $0.5 \%$ per degree Celsius, depending on the cell material used. Heat may be dissipated from the backside of the PV by both convection and radiation (conduction may be neglected). The rate of convective transfer to the backside of the unfinned PV is governed by Newton's law of cooling, as indicated in Equation (1) (Khan et al., 2020).

$$
Q_{c o n v}=h_{A s}(T s-T a)
$$

Where the area and temperature of the heat transfer surface area are denoted by As and Ts; Ta represents the ambient temperature and $\mathrm{h}$ represents the coefficient of convection heat transfer. As can be seen from Equation (1), it is clear that the heat transfer rate increases with the area of the heat transfer surface As (passive cooling). For this reason, the aluminum fins were used in this study to enhance the heat transfer rate. Heat may be transferred from the backside of finned PV by a complex process: convection and radiation between the surfaces of louver fins and the outside, and conduction through the fins. The heat dissipated from the fins mainly depends on fin height, material and geometry, the distance between the fins, and the fin thickness. Equation (2) governs the total heat transfer from fins; this includes the transfer of heat from both the finned 
and un-finned surface areas, which needs cooling (Khan et al., 2020).

$$
Q_{\text {tota, fin }}=n \cdot Q_{\text {unfin }}+n \eta_{f i n .} Q_{\text {fin }} .
$$

or,

$$
\left.Q_{\text {total }, \text { fin }}=n h_{\text {unfin }} A_{\text {unffin }} T_{s, \text { unffin }}-T a\right)+n h_{\text {fin }} A_{f i n} \eta_{f i n} T_{s, f i n}-T_{a)}
$$

where: $n$ is the number of fins attached to the back of the panel,

$T_{s, f i n}$ is the surface temperatures for the finned area,

$T_{s, u n f i n}$ is the surface temperatures for the unfinned area,

$h_{f i n}$ is the coefficient of the convection heat transfer for the finned area,

$h_{u n f i n}$ is the coefficient of the convection heat transfer for the unfinned area,

$A_{\text {unfin }}$ is the area of one of the fin,

$A_{f i n}$ is the area of the un-finned portion of the surface area.

The efficiency of the fin $\left(\eta_{f i n}\right)$ is defined as the ratio of the actual rate of heat transfer from the fin to the rate of heat transfer from the fin, ideally, if the whole fin was to be at the back surface temperature of the module. In addition to the heat loss by convection from the PV, radiation may play a significant role, which is given the equation (assuming ambient is the black body).

$$
Q_{r a d}=\varepsilon A_{s} F_{s-a}\left(T_{s}^{4}-T_{a}^{4}\right)
$$

View factor (configuration factor between the $\mathrm{PV}$ and ambient is denoted by $F_{s-a}$, the emissivity of the PV is $\varepsilon$ whereas the surface and ambient temperatures are $T_{s}$ and $T_{a}$, respectively. The rate of radiative heat loss from the surface increases with surface area, which increased by using fins and with the emissivity of the surface, which is enhanced by the nano-fluid used in this work (Wazwaz et al., 2010). As a result, in order to improve the efficiency of the cells, a reliable heat dissipation system is required to properly cool the cells. Tan et al. (2017) conducted experimental work to investigate the thermal and electrical performance of photovoltaic (PV) systems by comparing the latent heat-cooled PV panel with the naturally-cooled equivalent. They used organicbased paraffin wax as a phase change material, in which metallic fins were incorporated. They concluded that a drop in the temperature of the PV was $15^{\circ} \mathrm{C}$, compared to the naturally-cooled PV panel. The maximum electrical conversion efficiency improvement of $5.39 \%$ was achieved by the proposed passive cooling approach. Bahaidarah et al. (2013) built a numerical model (electrical and thermal). Various electrical and thermal characteristics impacting its performance were predicted by the model. The module was also examined experimentally by placing a heat exchanger (cooling panel) on its back surface. The results of the numerical model were found to be in good agreement with the experimental one. The climatic data were taken in Dhahran, Saudi Arabia. The temperature of the modules was reduced by around $20 \%$ with active water cooling, resulting in a 9 percent gain in PV panel efficiency.

Hamdan and Kardasi (2017) explored the effect of cooling on the performance of four identical photovoltaic (PV) panels set side by side. One was used as a baseline, the second was cooled using pure water, and the third was cooled using nano-fluids. To produce the nanofluid, aluminum oxide $\left(\mathrm{Al}_{2} \mathrm{O}_{3}\right)$ and copper oxide $(\mathrm{CuO})$ nanoparticles were introduced to pure water at varying concentrations, in order to find the most suitable concentration of $\mathrm{Al}_{2} \mathrm{O}_{3}$ and $\mathrm{CuO}$. They discovered that mixing 0.4 percent $\mathrm{Al}_{2} \mathrm{O}_{3}$ by weight with clean water increased the panel efficiency by $2 \%$. When 0.6 percent $\mathrm{CuO}$ was added, the efficiency increased by $2.34 \%$.

An experiment on the performance of PV panels was conducted by using finned aluminum plates and natural convection cooling was carried out by El Mays et al. (2017). The adoption of an aluminum finned plate enhanced the efficiency of solar to electricity conversion by $1.75 \%$ and the output power by 1.86 Watt. Hamdan et al. (2018) conducted a study to see if using phase change materials to cool photovoltaic panels (PV) could increase their performance (PCM). For comparison, they used two identical PV panels, one with PCM on the backside and the other with a standard PV panel. The generated currents and voltages, ambient and PV panel temperatures and incident solar irradiance were all recorded and stored using a data collection system. The stored data were examined, and it was discovered that the PCM-cooled PV panel was the most efficient and performed 2.6 percent better than the base panel. To minimize the temperature of solar panels, Firoozezadeh et al. (2019) placed a number of aluminum fins on the back surface of the panels under two distinct irradiations. This experiment was carried out at $85^{\circ} \mathrm{C}$, which is the maximum 
operating temperature of solar modules. The number of aluminum fins on the backside surface of solar panels was used to compute the $t$ coefficient under two different irradiations. Temperatures were reduced by up to $7.4^{\circ} \mathrm{C}$, resulting in a 2.72 percent increase in efficiency. Finally, an economic assessment of the offered examples was carried out based on the generated power of PV panels, which revealed a suitable economic justification. Wongwuttanasatian et al. (2020), proposed passive cooling with a finned container filled with a phase change material (PCM) container heat sink to enhance the cooling process for a PV. They found out that it is possible to reduce the module temperature from $57.9^{\circ} \mathrm{C}$ to $51.8^{\circ} \mathrm{C}$ (a $6.1^{\circ} \mathrm{C}$ temperature drop). Thus, the module efficiency was enhanced from $9.33 \%$ to $9.82 \%$, corresponding to a $5.3 \%$ improvement.

Four different cooling systems, working on the photovoltaic (PV) panel back surface, were proposed and investigated by Bevilacqua et al., (2021). Hourly electrical output power and efficiency were measured. They demonstrated that a simple spray cooling technique can provide an absolute increment of electrical efficiency of up to $1.6 \%$ and an average percentage increment of daily energy of up to $8 \%$ in hot months. As indicated above, most of the previous work was conducted under active conditions. In this work, the thermal and electrical performance enhancement of PV panels was subjected to experiments under natural convection conditions and to enhance the cooling process, fins in the form of an automotive radiator (fins) were attached firmly to the backside. Furthermore, and to further enhance the cooling process, the backside of the finned and unfinned PV were coated by water-based aluminum oxide nanoparticles. Four identical PV panels were installed side by side to conduct the work instantaneously. The first Panel was the basic one and used for comparison purposes (B), the backside of the second one was coated with waterbased aluminum oxide nano-fluid $(\mathrm{BN})$, on the backside of the third one fins (automotive radiator) will be firmly attached $(\mathrm{F})$. The radiator (fins) coated by $\mathrm{AL}_{2} \mathrm{O}_{3}$ water-based nano-fluid (FN) were attached to the backside of the fourth PV.

\section{MATERIALS AND PROCEDURE}

\section{Materials}

The experimental setup was designed and installed to investigate the effect of aluminum fins and $\mathrm{Al}_{2} \mathrm{O}_{3}$ water-based nano-fluid on the performance of the photovoltaic panel, the main components of this experimental setup are four identical PV panels, I-V checker, Datalogger, and PC. The experiment setup is shown in figure (1). Four identical PVs (polycrystalline type) were used in this work. Their specifications are shown in table (1). Each PV of the four identical is PSP72 Poly-Crystalline Module with a maximum power of $345 \mathrm{Wp}$. The $\mathrm{Al}_{2} \mathrm{O}_{3}$ nanoparticles (alpha type) of $30 \mathrm{~nm}$ diameter were used in this work. These particles are water dispersion (suspensions of nanoparticles in water), which can be used asis or diluted with suitable (compatible) solvents. They were manufactured by US Research Nanomaterials, Inc. (Houston. USA)
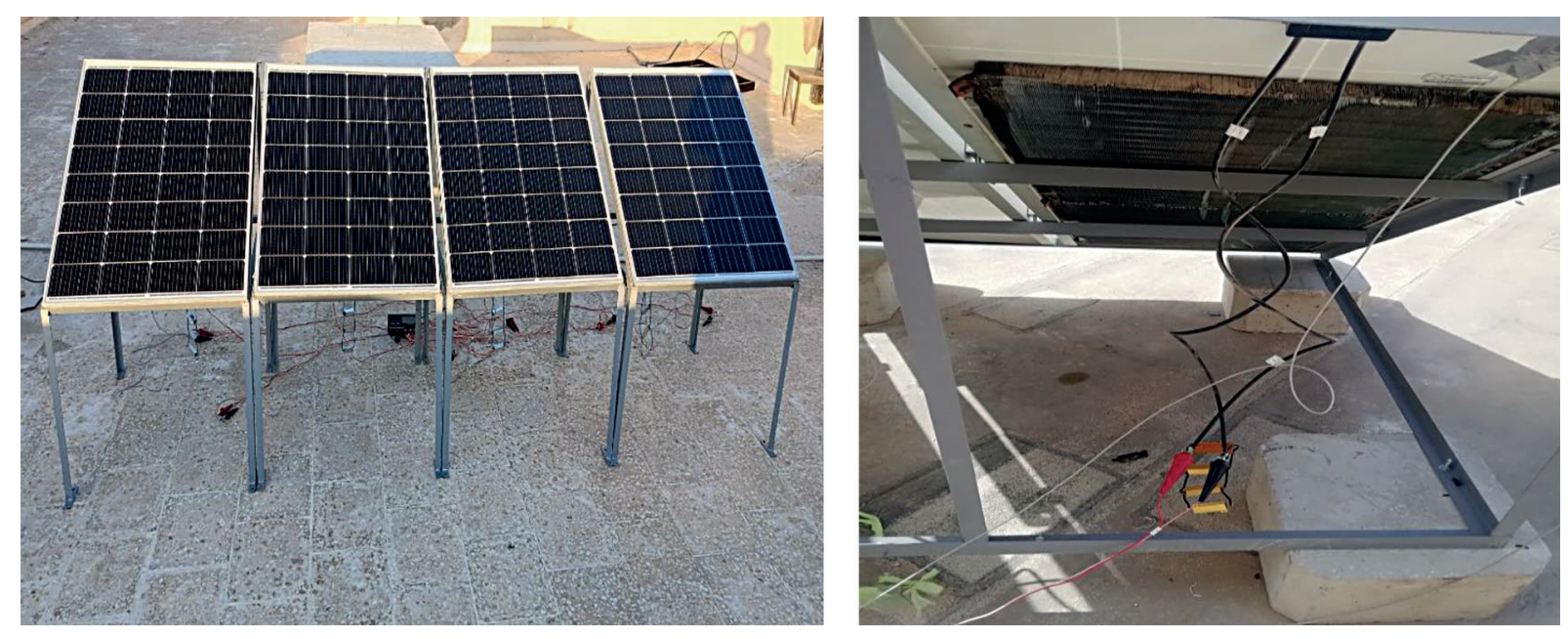

Figure 1. Experiment setup 
A radiator is made up of tubes, fins, and headers (all made of aluminum). Tubes and fins constitute the radiator matrix. The radiator block is made up with the addition of headers and side supports. The side supports serve to secure the radiator inside the sleeves on the backside of the $\mathrm{PV}$ and have an additional strengthening function. K-type thermocouples were also used for PV backside temperature measurement. These thermocouples were installed on three locations on the PV backside at the center and the average value was taken as that of the PV backside. Due to the very small thickness and very high thermal conductivity of the louvered fins in the radiator, it is reasonable to assume that they are isothermal ones. The temperature readings were recorded on an hourly basis and stored using a datalogger.

The GL220 data logger, which has a 2 GB internal flash memory for immediate data capture, and its USB interface may be connected to a PC for data upload in real-time or from memory. In addition it enables remote configuration and data gathering in real-time. An MP-170 I-V Checker, which allows the operator to do on-site accurate $\mathrm{I}-\mathrm{V}$ performance measurements and inspection of PV modules or arrays, was used to record and store the produced power from each PV. On the basis of the parameters (Vmax, Imax, Pmax, Voc, Isc, FF, Tmod, neff), it can measure the I-V curves of each PV module type. In addition, the I-V checker is equipped with control software such that the stored data may be converted into CSV file format and then the I-V curve measurement data are automatically converted into Standard Test Conditions (STC) values.

\section{METHOD}

The four panels were installed side by side for simultaneous testing, as shown in figure 1. The first one was used as a basis for comparison purposes, the second one was coated by $\mathrm{AL}_{2} \mathrm{O}_{3}$ water-based nano-fluid. In order to further cool down the third and fourth PV panels in a passive manner, a radiator, which acts as a heat sink made up of aluminum fins, was used. It was firmly attached to the backside of each PV by aluminum clamps located at each corner, such that was in direct contact with the PV. This was to avoid the air film between the radiator and the PV, and hence the contact resistance may be neglected. In addition to the attached fin, the backside of the fourth
Table 1. Electrical specification of PV

\begin{tabular}{|l|c|}
\hline Electrical characteristics $(\mathrm{STC})$ & $345 \mathrm{~W}$ \\
\hline Module System Voltage $(\mathrm{V})$ & $1000 / 1500$ \\
\hline Open Circuit Voltage - $\mathrm{V}_{\text {oc }}(\mathrm{V})$ & 46.62 \\
\hline Short Circuit Current - $\mathrm{I}_{\mathrm{sc}}(\mathrm{A})$ & 9.37 \\
\hline Maximum Power Voltage - $\mathrm{V}_{\mathrm{mpp}}(\mathrm{V})$ & 38.32 \\
\hline Maximum Power Current - $\mathrm{I}_{\mathrm{mpp}}(\mathrm{A})$ & 9.01 \\
\hline Maximum Power $-\mathrm{P}_{\max }(\mathrm{W})$ & 345 \\
\hline Module Efficiency $(\mu \%)$ & 17.7 \\
\hline
\end{tabular}

$\mathrm{PV}$ was sprayed by water-based $\mathrm{Al}_{2} \mathrm{O}_{3}$ nano-fluid. Three k-type thermocouples were attached at the rear side of each panel to take temperature readings from three spots in order to find the average temperature of the panel. The hourly measured temperature values are saved and stored in the GL220 data logger for further analysis. The produced power from each PV was recorded and stored and each I-V curve were measured and converted into CSV file format and then converted into STC values and displayed on the monitor used. It is to be noted that the ambient temperature and solar radiation values were measured using the GRWS100 weather station located on the site. The experiments were conducted from 9.00 am to $5.00 \mathrm{pm}$ and the data was registered every 20 min for without and with heat sink, concurrently. The experiment was repeated more than one time on different dates to confirm the results. All devices have been previously calibrated.

\section{RESULTS AND DISCUSSIONS}

Figure 2 shows the hourly average backside temperature of the four panels. As shown in the figure, the surface temperature of the $(\mathrm{CN}) \mathrm{PV}$ panel is $31^{\circ} \mathrm{C}$, which is the lowest among the other three panels, followed by the $(\mathrm{N}),(\mathrm{F})$, and (B) PV panels, respectively, as a result a drop in the average temperature of the backside of the PV equal to $8^{\circ} \mathrm{C}$ was obtained. In addition, as indicated, all PVs have a temperature above the ambient temperature. This means that the finned and coated PV's cooling mechanism is more efficient than the finned and base PV's. This is because the fins promote heat loss from the backside of the PV by both convection and radiation when passing air flows across the fins, and the emissivity of Aluminum is higher than that of the back side. Furthermore, the presence of $\mathrm{Al}_{2} \mathrm{O}_{3}$ nanoparticles 


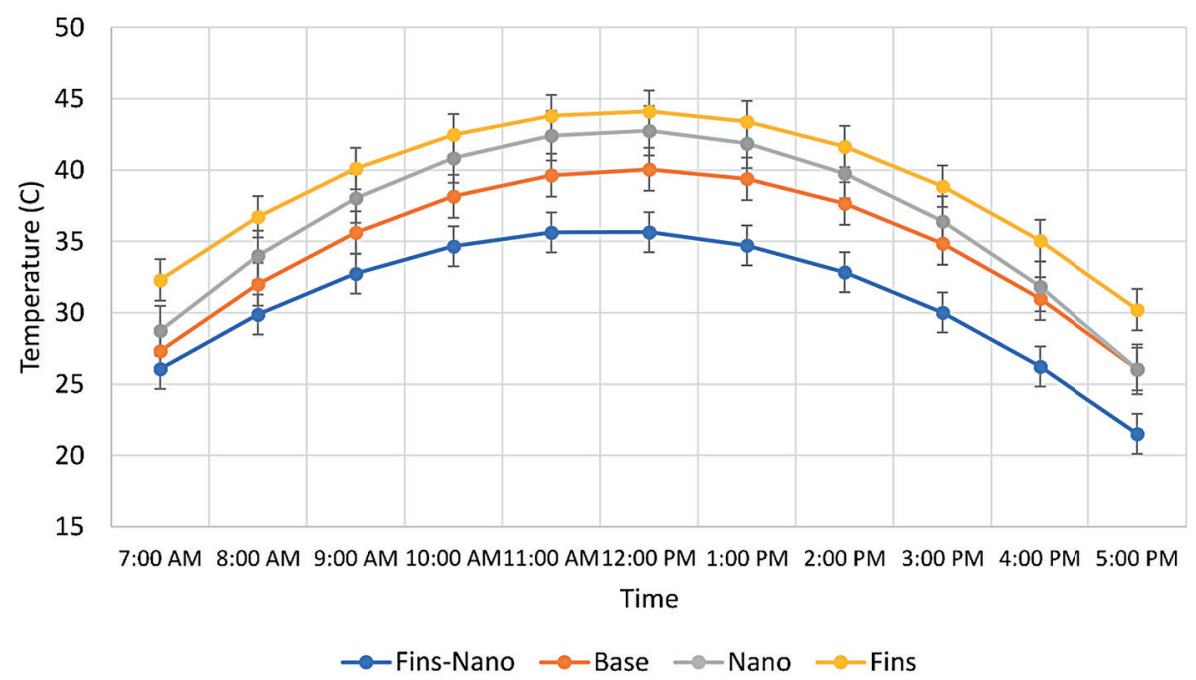

Figure 2. Hourly average temperatures of panels

boosts the emissivity of the coated fins, which improves the cooling process and results in a greater reduction in the backside temperature of the finned and coated PV. Moreover, from this figure it may be noted that the cooling process of $(\mathrm{N})$ $\mathrm{PV}$ is more efficient than that of the (F) PV cooling process; this is due to the fact that the $\mathrm{Al}_{2} \mathrm{O}_{3}$ nanoparticles enhance the heat dissipation from the backside of the PV this is caused by the relatively high emissivity of $\mathrm{Al}_{2} \mathrm{O}_{3}$ nanoparticles. Finally, the figure indicated that the aluminum fins increase the heat loss from the backside of the $(\mathrm{F})$ PV compared with the (B) PV. It is expected that this is caused by the increase in the surface area from which heat is being lost to the surroundings once fins are attached. The temperature reduction reported in this study is compared to other previously published studies that used various types of heat sinks to cool PV modules. The findings in Table 2 clearly demonstrate that the mechanism outlined in this study is a successful one.

Figure 3 represents the I-V curves of the four $\mathrm{PV}$ as obtained directly from the I-V checker, for each point on the $\mathrm{I}-\mathrm{V}$ curve, the product of the current and voltage represent the output power for that operating condition. The MPP produced by the cell is reached at a point on the characteristic curve where the product $\mathrm{I}-\mathrm{V}$ is maximum. It

Table 2. Comparison with other published works

\begin{tabular}{|l|l|c|c|c|}
\hline \multicolumn{1}{|c|}{ Reference No } & \multicolumn{1}{|c|}{ Cooling method } & $\begin{array}{c}\text { Temperature without } \\
\text { cooling }\left(\mathrm{C}^{\circ}\right)\end{array}$ & $\begin{array}{c}\text { Temperature with } \\
\text { cooling }\left(\mathrm{C}^{\circ}\right)\end{array}$ & $\begin{array}{c}\text { Temperature reduction } \\
\left(\mathrm{C}^{\circ}\right)\end{array}$ \\
\hline Present study & $\begin{array}{l}\mathrm{Al}_{2} \mathrm{O}_{3} \text { nano coated } \\
\text { automotive radiator }\end{array}$ & 39 & 31 & 15 \\
\hline Tan et al.,(2017) & $\begin{array}{l}\text { latent heat-cooled PV } \\
\text { panel }\end{array}$ & 40 & 55 & 5.90 \\
\hline Chandrasekar et al. (2016) & $\begin{array}{l}\text { Conjunction fins and } \\
\text { cotton wicks }\end{array}$ & 49.2 & 43.3 & 6.1 \\
\hline El Mays et al. (2017) & Finned aluminum plate & 56 & 49.9 & 1 \\
\hline Selimefendigi et al. (2018) & Aluminum fin & 49 & 48 & 5.9 \\
\hline Chandrasekar et al. (2015) & Aluminum spreader & 49.2 & 70.4 & $5-7$ \\
\hline Micheli et al. (2015) & $\begin{array}{l}\text { Silicon micro-finned } \\
\text { heat sinks }\end{array}$ & 78.8 & 38 & 2 \\
\hline $\begin{array}{l}\text { Hernandez-Perez et al. } \\
\text { (2021) }\end{array}$ & $\begin{array}{l}\text { Discontinuous finned } \\
\text { heat sink (numerical } \\
\text { and experimental) }\end{array}$ & 49 & 55 & 14.6 \\
\hline Gomaa et al. (2020) & U shaped fins cooling & 57 & 35.74 & 7.3 \\
\hline Gyekum et al. (2021) & $\begin{array}{l}\text { Aluminum fins + } \\
\text { ultrasonic humidifier }\end{array}$ & 50.35 & 37.8 & 6.1 \\
\hline Bahaidarah et al. (2013) & Water cooling & 30.5 & 57.9 & \\
\hline $\begin{array}{l}\text { Wongwuttanasatian et al. } \\
\text { (2020) }\end{array}$ & $\begin{array}{l}\text { finned container filled } \\
\text { with (PCM) }\end{array}$ & 51.8 & & \\
\hline
\end{tabular}




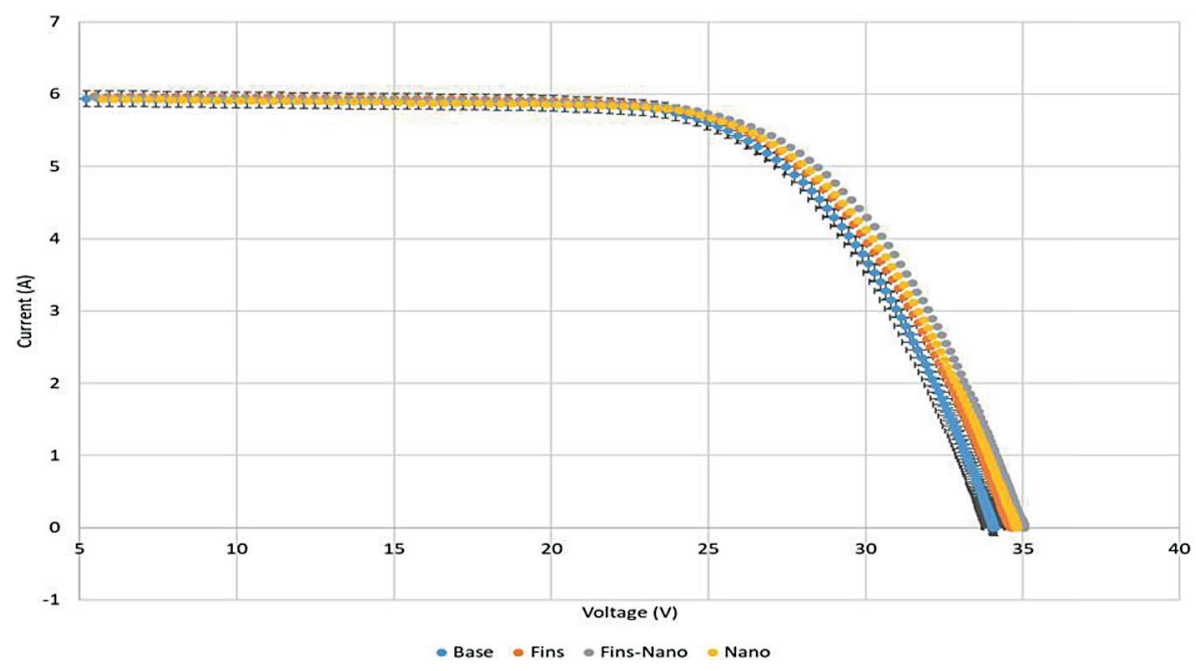

Figure 3. Current-voltage curves of all panels

may be noticed from the figure that the power produced by (FN) exceeds those of other PV, followed by that produced by $(\mathrm{N})$ that exceeds the power produced by $(\mathrm{F})$, while (B) PV produces the least amount of power. This agrees with the findings presented in figure 2 , since the power produced by the PV decreases with the PV temperature.

Figure 4 illustrates the average hourly output power of the panels, as it can be seen, and compared to the power produced by the basic panel, the coated and finned PV panel performed the best, followed by the nano-coated PV and the finned one produced the least power. This is due to the fact that the power output of PVs reduces when the backside temperature rises. As it can be seen in this graph, the finned and coated PVs produced 5.77\% more power than the basic one and the nano-coated PV produces $2.14 \%$. Finally, the finned PV produced $0.74 \%$ more power than the basic PV.

\section{CONCLUSIONS}

In this study, the performance of the photovoltaic panel was investigated by the enhancement of natural cooling. This was achieved by using the $\mathrm{Al}_{2} \mathrm{O}_{3}$ water-based nano-fluid, together with aluminum fins on the backside of three identical panels. An additional panel was used as a basic panel for comparison purposes. The first one (B) was a basic PV that was used for comparison purposes, the second $(\mathrm{N}) \mathrm{PV}$, was coated with water

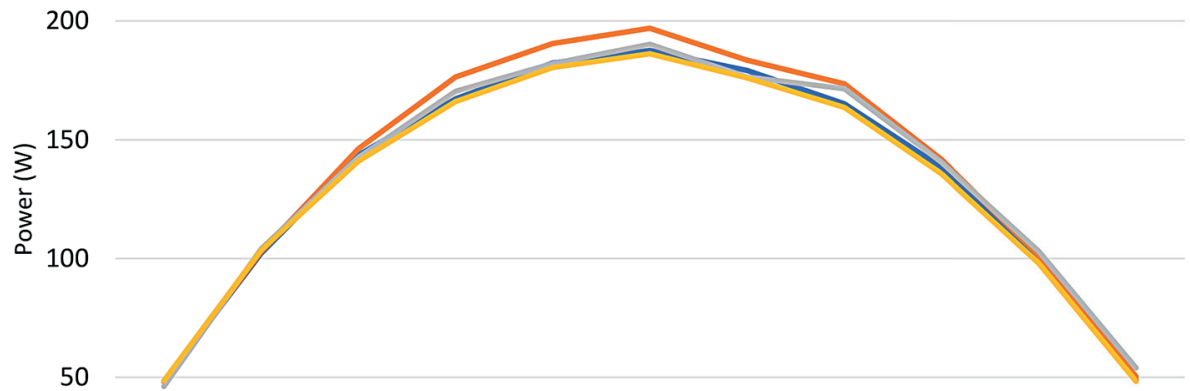

7:00 AM 8:00 AM 9:00 AM 10:00 AM 11:00 AM 12:00 PM 1:00 PM 2:00 PM 3:00 PM 4:00 PM 5:00 PM
Time -Fins - Fins- Nano Nano - Base

Figure 4. Average hourly produced power by all panels 
base $\mathrm{Al}_{2} \mathrm{O}_{3}$ nanofluid, the third was finned $\mathrm{PV}(\mathrm{F})$, with fins being attached to its backside and the fourth $\mathrm{PV}(\mathrm{FN})$, had $\mathrm{Al}_{2} \mathrm{O}_{3}$ nano-fluid coated fins attached to its backside. It may be concluded that the cooling mechanism of the panel has been enhanced the most when the finned back side of the panel was coated by $\mathrm{Al}_{2} \mathrm{O}_{3}$ water-based nanofluid, followed by the case when the backside is backside only coated by $\mathrm{Al}_{2} \mathrm{O}_{3}$ water-based nanofluid and the least enhancement was when fins were attached to its backside. Consequently, and compared to the basic panel, it may be concluded that the performance of the finned and nano-coated PV panel was the highest, followed by the nanocoated one, while the finned one exhibited the least enhancement in its performance.

\section{Acknowledgments}

This work was conducted during the author's sabbatical leave, granted to him at the University of Jordan.

\section{REFERENCES}

1. Bahaidarah H., Subhan A., Gandhidasan P., Rehman S. 2013. Performance evaluation of a PV (photovoltaic) module by back surface water cooling for hot climatic conditions. Energy, 59, 445-453.

2. Bayrak F., Oztop H.F., Selimefendigil F. 2020. Experimental study for the application of different cooling techniques in photovoltaic (PV) panels. Energy Conversion and Management, 212.

3. Bevilacqua P., Perrella S., Cirone D., Bruno R., Arcuri N. 2021. Efficiency Improvement of Photovoltaic Modules via Back Surface Cooling. Energies, 14, 895.

4. Chandrasekar M., Senthilkumar T. 2015. Experimental demonstration of enhanced solar energy utilization in flat PV (photovoltaic) modules cooled by heat spreaders in conjunction with cotton wick structures. Energy, 90, 1401-1410.

5. Chandrasekar M., Senthilkumar T. 2016. Passive thermal regulation of flat PV modules by coupling the mechanisms of evaporative and fin cooling. Heat Mass Transf, 52, 1381-1391.

6. Chen H., Chen X., Li S., Ding H., et al. 2014. Comparative study on the performance improvement of photovoltaic panel with passive cooling under natural ventilation. Int J Smart Grid Clean Energy, 3(4), 349-374.

7. Daghigh R., Ruslan M.H., Sopian K. 2011. Advances in liquid based photovoltaic/thermal (PV/T) collectors. Renewable and Sustainable Energy Reviews, 15(8), 4156-4170.'
8. El Mays A., Ammar R., Hawa M., Akroush M., Hachem F., Khaled M., Ramadan M. 2017. Improving photovoltaic panel using finned plate of aluminum. Energy Proc, 119, 812-817.

9. El Mays A., Ammar R., Hawa M., Akroush M.A., Hachem F., Khaled M., Ramadan M. 2017. Improving Photovoltaic Panel Using Finned Plate of Aluminum. Energy Procedia, 119, 812-817.

10. Firoozzadeh M., Shiravi1 A.H., Shafiee M. 2019. An Experimental Study on Cooling the Photovoltaic Modules by Fins to Improve Power Generation: Economic Assessment, Iranian (Iranica). Journal of Energy and Environment, 10(2), 80-84.

11. Gomaa M.R., Hammad W., Al-Dhaifallah M., Rezk H. 2020. Performance enhancement of grid-tied PV system through proposed design cooling techniques: An experimental study and comparative analysis. Sol. Energy, 211, 1110-1127.

12. Grubišić-Čabo F., Nižetić S., Marco G. 2016. Photovoltaic Panels: T. A Review of the Cooling Techniques, Transactions of Famena XL, Special issue 1.

13. Gyekum E.B., Praveen Kumar S., Alwan N.T., Velkin V.I., Shcheklein S.E., Yaqoob S.J. 2021. Experimental Investigation of the Effect of a Combination of Active and Passive Cooling Mechanism on the Thermal Characteristics and Efficiency of Solar PV Module. Inventions, 6, 6

14. Hamdan M., Shehadeh M., Al Aboushi A., Hamdan A., Abdelhafez E. 2018. Photovoltaic Cooling Using Phase Change Material, Jordan Journal of Mechanical and Industrial Engineering, 12(3), 167-170.

15. Hamdan M.A., Kardasi K.K. 2017. Improvement of photovoltaic panel efficiency using nanofluid. Int. J. of Thermal \& Environmental Engineering, 14(2), 143-151.

16. Hernandez-Perez J.G., Carrillo J.G., Bassam A., FlotaBanuelos M., Patino-Lopez L. 2021. Thermal performance of a discontinuous finned heatsink profile for PV passive cooling. Appl. Therm. Eng., 184, 116238.

17. Khan S., Waqas A., Ahmad N., Mahmood M., Shahzad N., Sajid M.B. 2020. Thermal management of solar PV module by using hollow rectangular aluminum fins. J. Renew. Sustain. Energy, 12, 063501.

18. Krauter S. 2004. Increased electrical yield via water flow over the front of photovoltaic panels. Solar energy materials and solar cells, 82(1-2), 131-137.

19. Kumar R., Rosen M.A. 2011. A critical review of photovoltaic-thermal solar collectors for air heating. Applied Energy, 88(11), 3603-3614.

20. Makki A., Omer S., Sabir H. 2015. Advancements in hybrid photovoltaic systems for enhanced solar cells performance. Renewable and sustainable energy reviews, 41, 658-684.)

21. Micheli L., Senthilarasu S., Reddy K.S., Mallick T.K. 2015. Applicability of silicon micro-finned 
heat sinks for $500 \mathrm{x}$ concentrating photovoltaics systems. J. Mater. Sci., 50, 5378-5388.

22. Ogueke N.V., Anyanwu E.E. 2017. Review of Photovoltaic-Thermal Collectors: An Overview of the Potential beyond Experimental Testing. International Journal of Energy for a Clean Environment, 18(3).

23. Royne A., Dey C. J., Mills D.R. 2005. Cooling of photovoltaic cells under concentrated illumination: a critical review. Solar energy materials and solar cells, 86(4), 451-483.

24. Selimefendigil F., Bayrak F., Oztop H.F. 2018. Experimental analysis and dynamic modeling of a photovoltaic module with porous fins. Renew. Energy, 125, 193-205.

25. Smith M.K., Selbak H., Wamser C.C., Day N.U., Krieske M., Sailor D.J., Rosenstiel T.N. 2014. Water cooling method to improve the performance of field-mounted, insulated, and concentrating photovoltaic modules. Journal of Solar Energy Engineering, 136(3).

26. Tan L., Date A., Fernandes G., Singh B., Ganguly S. 2017. Efficiency Gains of Photovoltaic System Using Latent Heat Thermal Energy Storage. Energy Procedia, 110, 83-88.

27. Wazwaz A., Salmi J., Bes R. 2010. The effects of nickel-pigmented aluminum oxide selective coating over aluminum alloy on the optical properties and thermal efficiency of the selective absorber prepared by alternate and reverse periodic plating technique. Energy Conversion and Management, 51(8).

28. Wongwuttanasatian T., Sarikarin T., Suksri A. 2020. Performance enhancement of a photovoltaic module by passive cooling using phase change material in a finned container heat sink. Sol. Energy, 195, 47-53. 
